\title{
The Manifestation of Alienation in Sylvia Plath's the Bell Jar
}

\author{
Esma Biroğlu \\ English Language and Literature Department \\ Istanbul Aydın University \\ Turkey-Istanbul
}

\begin{abstract}
This study argues that the male-dominated society alienates the protagonist of The Bell Jar, Esther, as she tries to develop her female identity in the patriarchal American society. The American society obligated women to be submissive to their husbands. Women were expected to satisfy their husband's sexual desires and become mothers. Secondly, the paper sheds light on other reasons behind the protagonist's alienation like being different from her society in general and mother in particular. She alienates herself from the conventional thinking among American women who believe in "idle talk," where they lack the choice to change anything concerning the world. Esther does not desire to live within the confinements of the societal gender roles; therefore, she dissociates herself from her family and environment. Thirdly, the study illustrates how the psychological trauma, inner absence, and depression alienate the protagonist. She misses her deceased father. What is more, his absence ushers her miserableness, depression and madness. Additionally, the meaninglessness in her life makes her unable to enjoy her life to the fullest. Thus, this state makes her sadder, depressed, and more alienated.
\end{abstract}

Keywords: alienation, madness, identity, trauma, patriarchy

\section{Introduction}

\section{The Definition and History of Alienation}

The term alienation refers to the presence of estrangements between people's relationship with diverse elements in their environment. The term is open to multiple psychological and philosophical interpretations. Notably, the word became popular in the nineteenth century from Hegel's school of thought. Thinkers and philosophers later developed the notion further in the twentieth century.

Hegel developed the idea of alienation by perceiving history as a dialectical revelation of spirit. In this case, the philosopher believes that the spiritis separated from the objective world; thus, it is alienated from itself. Moreover, Hegel through his slave dialect defined alienation as the desire to have one's consciousness recognized by another without reciprocating the same. However, Jacque Lacan expounded on the same definition; he defined it as a person's desire to acquire meaning in another's desire. The situation is possible since an individual wants his aspirations to be recognized by others. Lacan proposed that the fundamental desire of human beings is to be perceived relevant by others. In this case, individuals are alienated since they can only understand themselves through others (Middleton, 1963).In the view of the father of psychoanalysis, Sigmund Freud suggested that" the essence of the process or repression lies, not in abrogating or annihilating the ideational presentation of an instinct, but in withholding it from becoming conscious" (Freud, 1963). In this case, past traumatizing effects remain in an unconscious state in an individual's mind and can cause traumatic effects in the future.

On the other hand, Karl Marx deviated from other thinkers in the definition of the term since he emphasized on economic, political, and social forces in history. He based his ideology on capitalism, which alienates a worker from the profits of the production process (Sarvaharana, Thiyagarajan, \& Manikandan, 2017).Workers lost their ability to think of themselves as the master of their doings; to determine the integrity of their actions; to own property, which they produced. In this case, the workers were directed towards the goals and objectives of the rich, who held the means of production (Musto, 2010). Thus, they were alienated from the human aspect of life.

In the twentieth century, Martin Heidegger expounded on existential alienation, which is the limitation of the human brain towards the world's perception. In this circumstance, people are limited to the "idle talk," where they discuss topics using the "they say" notion (Kanungo, 1979; Shepherd, 2015). The situation leaves them with nothing new to discover about the world. Idle talk is the human ability to understand ideologies without owning them. 
On the other hand, According to sociologist Melvin Seeman, alienation refers to a state at which a person becomes alienated from their environment and other people (Mann, 2001). They are often neglected or rejected by society and their loved ones, which makes them estranged and distanced from their emotions.

\section{Alienation in Literature}

Different authors have explored the notion of alienation based on patriarchal nature of diverse societies. The ideology of a male-dominatedsociety enables the authors to develop the theme of alienation via characters in their works of literature. The novel Surfacing by Margret Atwood is an example of literature that explores alienation extensively. In this case, the author reveals the absolute alienation of Canadian women in the society. She uses the alienation of the protagonist to depict the everyday alienation of Canadian women due to the chauvinistic nature of the community (Christ, 1976). The narrator, who is the protagonist, constantly feels isolated from the world around her. She is separated from her parents since her father is missing and she is detached from her mother. Notably, she perceives men as alienating because of their attempts to control women concerning marriage, religion, sex, birth, and language (Özdemir, 2003). She also reveals how Canadian men believe that relationships are wars, where women are war-spoils. For instance, she narrates of how her husband forced her to abort her child and later abandoned her.

Moreover, Atwood reveals the depth of the alienation by showing how the narrator's current lover embraces never aroused her. The situation reveals her total alienation from men. Additionally, the narrator exposes her alienation as systematic by showing how children discover their gender roles at a tender age. As a result, the she is completely withdrawn from the normal life. Clearly, Atwood does not reveal the name of the narrator throughout the story for her to serve as a universal figure.

Another example of alienation can be seen in Jean Rhys's Wide Sargasso Sea which highlights the complexities of the human psyche as shaped by gender and racial segregation. In the novel, the protagonist, Antoinette struggles with her identity amidst racial and gender prejudice in the Caribbean islands. She is a Creole who is born of an English father and Indian mother; therefore, she is alienated from the Jamaican colony where she is perceived as an outsider (Gonçalves, 2017).). The male-dominated colonizers try to alienate Antoinette through legal restrictions and ostracism as she strives to create her own identity. Additionally, she faces dissent from her black friends and neighbors. In the light of this event, one may view Rhys's work as a representation of a woman's journey to madness to evade male domination (Louati, 2016). Significantly, the author, Jean Rhys is a Creole, which makes Antoinette narrative a representation of her alienation and exile life in England.

The theme of alienation attracted the above authors and many others like Samuel Beckett, Mark Twain, and J.D. Salinger. Obviously, alienation will continue to draw attention of many writers in the future. The condition is possible since most societies around the world are male-dominated, which poses many challenges to women.

\section{Alienation in the Bell Jar}

\section{Male Dominated Society}

Sylvia Plath's novel The Bell Jar focuses on the alienation of Esther - the protagonist - as she tries to develop her female identity in a patriarchal society at the wake of the Cold War (Smith, 2008). She despises the male-dominated the culture of her community, which makes her hate the idea of being married. The author reveals images of blood, sickness, and vomiting that can be inferred to symbolize the ineffective environment, which she dissents though she lacks options, but to live in the same society. The society expects women to live as men companions to satisfy their sexual desires in marriage. Evidently, women are supposed to be subjective to their husbands. The above elements alienate Esther as she tries to detach herself from the reality and limitations in her surroundings. For example, she writes articles for magazines that advocate for consumerism and femininity, which can only be satisfied through marriage and homemaking (Plath, 1972). Her community expects her to emulate her editors.

Moreover, the two elements of marriage and homemaking drive her to a mental solitude. The situation is revealed when she quotes her boyfriend's mother Mrs. Willard, a teacher, and a professor's wife, "what a man wants is a mate and what a woman wants is infinite security" and "what a man is, is an arrow into the future and what a woman is, is the place the arrow shoots off from" (Plath, 1972). In this case, she refers to the above words as one of the reasons why she never desired to get married. She did not like the idea that only men can provide women with infinite security. What is more, she despised being a homemaker, the place where a man shoots. She is detached from such mentality that was persistent with typical American women at the time. She wanted to achieve her ambitions not only as a parent and wife but also in diverse ways; in her definition, like the colored arrow of Fourth of July rocket which goes into different directions searching for change and excitement (Plath, 1972). Noticeably, she finds the society's desire to have her conform to the social norms to conflict with her interests. 
Furthermore, her alienation is evident when she admires prominent women in the novel, yet she disregards their human flaws, which are shaped by the chauvinistic environment. For instance, Mrs. Willard despite her successful career allows her husband to dominate her and treat her as he seems suitable. The situation makes the protagonist wonder how she can be successful and yet be married to the same dominating men.

On the other hand, her boyfriend — Buddy — thinks of her poems as trash and dust (Plath, 1972). She also confesses how her quest for love makes her boyfriend to dominate her since she accepts everything Buddy tells her as the truth.

Besides, once in New York City, the author portrays Esther as alienated from the social fabrics of the region. The city describes men as the epitome of its success, and their association with their spouses defines women's progress. For example, only when Buddy visits Esther in college that other girls start respecting her regardless of their past unfriendliness. Nevertheless, she refuses to conform to the ideology since despite her desire to be loved and associate with men; she views them as hypocrites and exploiters. The phenomenon is evident when she despises her boyfriend for confessing of sleeping with a waiteress (Plath, 1972). Initially, Buddy introduced himself as an innocent man, which made Esther feel experienced in love more than him. Albeit, he was hypocritical, which made Esther decide not to get married to him

Esther's detachment from her social life resonates with the profound sociologist Seeman's theory of alienation. Seeman proposes that people feel alienated from their friends, family, and social environment due to deficiencies (Mann, 2001). In this case, the protagonist desires a life of solitude compared to associating with her deceptive society.

\section{Outsiderness}

Esther separates herself from the conventional thinking among American women, which aligns with Martin Heidegger's theory of existential alienation. In this case, people are limited within the confinements of their societal culture. Other women in the novel believe in "idle talk," where they lack the choice to change anything concerning the world. Esther does not desire to limit herself to the societal gender roles; therefore, she dissociates from her family and environment (Steinbeck, 2016). The phenomenon alienates her from other women in the novel. She cannot relate with any woman in the story, not even her mother whom she does not trust.

As a result, she embarks on a journey in search of a new identity which is different from other women's identities. Explicitly, she wants to be a poet, despite her boyfriend's discouragements. The situation makes her become an outsider in her community and social circle (Steinbeck, 2016). For instance, since she does not adore men, as it is the case with other girls of her age, they perceive her as unfriendly. She feels sidelined from the society mentally and emotionally.

Additionally, she rises beyond her confinements as a woman when she decides to explore her diversity as a woman. She sought to break her virginity with another man after realizing that her boyfriend was unfaithful (Mozumder, 2017). The ordeal made her pursue various men such as the UN interpreter. In the process, one of her spouses tries to rape her, which affects her future mental stability. During this period, it was unlikely for women to pursue men to satisfy their sexual desires; the men sought women (Mozumder, 2017).

Moreover, she is detached from her mother's aspirations for security, happiness, and domesticity. Just like other women, her mother leads a secret double life but still imposes the norms on her daughter (Benard, 2011). For example, she despises shorthand but forces Esther to learn about it. The situation makes the protagonist feel resented and guilt for harboring the burden of satisfying her mother's expectations as well as hers. She expects Esther to fulfill her social obligations regardless of her needs, which makes the protagonist stay away from home (Axelrod, 2010). She notes that "never living in the same house with my mother for more than a week" (Plath, 1972). The condition also makes her view her mother as a hypocrite like the others.

\section{Psychological Trauma}

The protagonist struggles with psychological torture throughout the narrative. Notably, the title The Bell Jar symbolizes the psychological and emotional confinements that burden Esther. Additionally, it is also a metaphor for her depression, which covers her, alters her perception towards life, and separates her from the real world (Parhizgar, 2010). She says that "stewing in my ownsour air," under the jar, which meant she was trapped in her depressive thoughts (Plath 1972). According to Sigmund Freud's psychoanalysis, unconscious thoughts from an individual's childhood have a substantial effect on their adult life (Freud, 1963). Traumatic events are hidden from a person's consciousness to become repressed thoughts. The thoughts can cause depression in the form of neuroses. In this case, Esther's past events lost within her consciousness caused her stress in the wake of her adulthood. 
In addition to her depressive state, the protagonist has feelings of inner absence. She misses her father who died while she was at the age of nine, which caused her depression. She confesses to having never been happy since her father's death. The situation continues to deteriorate until its peak when she returns from New York City, which makes her insane. In contrast, the novel infers to the author's life, Sylvia Path, who committed suicide in 1972, the same year the bookwas published due to mental complications. Unluckily, at the time of Esther's mental sickness, an information gap existed in the American Psychological Association manual. As a result, her mental case was classified as madness, and she was alienated from society. She was taken to an insane asylum where she is controlled and treated with fallacious methods.

\section{Meaninglessness and Purposelessness}

In the novel, Esther feels emotionally empty and unsatisfied, which makes her jealous of other privileged girls? During their tour to New York City, she narrates: I guess I should have been excited the way most of the other girls were, but I couldn't get myself to react. I felt very still and very empty, the way the eye of a tornado must feel, moving dully along in the middle of the surrounding hullabaloo. (Plath, 1972)

As a result, the protagonist seeks satisfaction in many ways, which were not common among typical American women at the time. In her life, she feels empty in such a way that her scholarship awards and prize winnings do not satisfy her. She confesses how she spent nineteen years of her life chasing after good marks, grants, and prizes yet she was giving up slowly.

Secondly, in New York City, she is dissatisfied with herself since she cannot enjoy her days like other girls. Due to her depression, she cannot attend shows, films, or luncheon as her friend Doreen. The protagonist wonders how she cannot conduct her activities for the full day as she once did. The condition makes her sad and tired with life. While in her room, she feels the emptiness every time as she stares on the white ceiling, while other girls are happily going for the show (Plath, 1972). Her emptiness alienates her from her peers in such a way that she does not enjoy the parties and entertainment activities that were provided in their internship.

Thirdly, her ambitions for success and career life made her feel empty and meaningless. She always imagined that she would be a successful editor, a professor, or a poetry writer. Esther believed in her abilities to accomplish whatever she desired and to live her life to the fullest. Nevertheless, after her interaction with Buddy and other successful women like Mrs. Willard, she was disillusioned (Plath, 1972) She developed feelings of discontent towards the life of a "successful American woman," and discovers that she was no longer interested in making a career.

\section{Treatment and Journey to Recovery}

All the above factors left Esther with no option to achieve a meaningful life. She chose not to suffer under the suffocating and humiliating social fabrics of her society; instead, she opted to commit suicide. Her previous predicaments were to pursue multiple goals that would bring her satisfaction, but she failed in the endeavors. Death offered an easy way to escape her misery.

According to Lugo (2010), mental institutions in the society are meant to bring back to society lost individuals. In the mental hospital, she is treated with electroconvulsive therapy, which inflicts much pain on her. She even wonders what she had done to deserve the pain. Stevens (1997) notes that electric-shock treatment causes damage to the brain, memory loss, and reduced intelligence. As a result, an individual is disoriented and confused, which makes them forget their current problems. Therefore, Esther's treatment in the mental facility is inhumane and corrosive since it aimed at eliminating her sensitivities and desire for a meaningful life. Instead of removing the social restrictions, the treatment erased her awareness that her personal needs were not being met in the current social context.

After her interaction with Dr. Nolan, she changed her perception towards life and gained the desire to live a better life. For instance, she explained to the doctor of her fears to become pregnant. Luckily, Dr. Nolan referred her to a physician who advised her on the use of a diaphragm during sex (Plath, 1972). As a result, the protagonist feltrelieved from sexual consequences and the burden to be a mother. She got over the pressures of getting married to the wrong person. Notably, under the watch of Dr. Nolan, her attitude towards life improved, which enabled her to regain her sanity. The novel ends with her being interviewed with the aim of starting a new life.

\section{Conclusion}

Overall, feminist novelists in the past have explored in-depth the theme of alienation in women in diverse societies with the aim of providing alternative solutions through literature. Explicitly, the complex wisdom in the novel reveals that an empty life with no avenues for fulfillment is not worth living. The protagonist is detached entirely from her environment, which makes her depressed and instills her with suicidal thoughts. 
Esther's misery is caused by the inability of the American social life to provide fulfillment for an ambitious woman, her imaginations on how life ought to be, and the disappointment with the real world. Blatantly, the novel is set in an era characterized by male-dominated norms that advocated for prescriptive women roles and cultural containment in an American conformist, conservative, and suburban setting. From the beginning of the narrative, the author reveals how Esther is detached from her surrounding as she tries to adapt to the social norms.

Moreover, the protagonist is alienated from other women in the novel since she has different attitudes and perception towards life. She believes that women can achieve their goals without being submissive to men. Furthermore, the novel reveals how the psychological trauma, depression, and misery can lead to the alienation of individuals from their societies. Esther is trapped by her grief and stress, which lead to her attempted suicide. However, she decides to take a turn in life by overcoming her fears and seeking psychological assistance to relieve herself of depressive thoughts, senses of meaninglessness, emptiness, and personal dissatisfaction.

\section{References}

Axelrod, S. G. (2010). Alienation and Renewal in The Bell Jar. Plath Profiles: An Interdisciplinary Journal for Sylvia Plath Studies, 3, 134-143.

Benard, L. A. (2011). Taking on a mourning her mother never bothered with: Esther's anguished memory and her resistance to a domestic life in Sylvia Plath's The Bell Jar. Plath Profiles: An Interdisciplinary Journal for Sylvia Plath Studies, 4, 291-299.

Christ, C. P. (1976). Margaret Atwood: the surfacing of women's spiritual quest and vision. Signs: Journal of Women in Culture and Society, 2(2), 316-330.

Freud, S. (1963). General Psychological Theory, New York: Macmillan.

Gonçalves, D. S. (2017).Drowning in a Wide Sargasso Patriarchy: The borderland's revision of female prototypes. Todas as Letras-Revista de Língua e Literatura, 19(3).

Kanungo, R. N. (1979). The concepts of alienation and involvement revisited. Psychological Bulletin, 86(1), 119.

Louati, A. (2016). The Liberating Force of the Carnival (esque) in Jean Rhys's Wide SargassoSea (1966). International Journal of Humanities and Cultural Studies (IJHCS) ISSN 2356-5926, 3(1), 741-749.

Lugo, A. (2010). The Female Predicament in The Bell Jar and St. Mawr. Plath Profiles: An Interdisciplinary Journal for Sylvia Plath Studies, 3, 144-165.

Mann, S. J. (2001). Alternative perspectives on the student experience: Alienation and engagement. Studies in Higher Education, 26(1), 7-19.

Middleton, R. (1963). Alienation, race, and education. American Sociological Review, 28(6), 973-977.

Mozumder, S. C. (2017). Love, sex and the body in the bell jar and my story: A feminist reading. A Journal of English Studies, 8.

Musto, M. (2010).Revisiting Marx's concept of alienation. Socialism and Democracy, 24(3), 79-101.

Özdemir, E. (2003). Power, madness, and gender identity in MargaretAtwood'sSurfacing: a feminist reading. English Studies, 84(1), 57-79.

Parhizgar, F. (2010). Trapped under The Bell Jar or Isolated in the Rye: A Study of Alienation and Gender Roles in the Two Novels. Submission Guidelines, 7, pp. 1-22.

Plath, S. (1972). The Bell Jar. New York: A Bantam Books, Inc.

Sarvaharana, P., Thiyagarajan, P., \&Manikandan, S. (2017). A study on BharatRatnadr. MgRamachandran's philosophical film songs with special reference to the socialistic and communistic ideas it contains-an academic comparative analysis with the theory of socialism as propounded by Karl Marx. World Journal of Social Science, 5(1), 46.

Shepherd, R. J. (2015). Why Heidegger did not travel: Existential angst, authenticity, and tourist experiences. Annals of Tourism Research, 52, 60-71.

Smith, R. (2008). Seeing through The Bell Jar: distorted female identity in Cold War America. Aspeers,1, pp. 34-54.

Steinbeck, T. (2016). A woman born twice: Esther Greenwood's reconstruction of the female identity in a pervasively patriarchal 1950's America. Sprinkle: An Undergraduate Journal of Feminist and Queer Studies, 9.

Stevens, L. J.D (1997).Psychiatry's electroconvulsive shock treatment - a crime against humanity.Antipsychiatry.org. Retrieved fromhttp://www.antipsychiatry.org/ect.htm 